\title{
The Birth Registration Rate in Bangladesh Observed in Rural and Urban Region
}

\author{
Ms. Mehnaz Karim \\ Senior Lecturer, BRAC University \\ Department of Mathematics \& Natural Sciences. Dhaka, Bangladesh
}

\begin{abstract}
The aim of this study is to analyze the birth registration rate of Bangladesh where the data has been observed during the period of 2009. The intact geographical area of Bangladesh has been covered in this survey. The number of birth registration in the categories of gender, the areas where these children belong to, their mother's education have been focused in this write up based on the survey collected from Multiple Indicator Cluster Survey 2009 by Bangladesh Bureau of Statistics. Later on some graphs and analysis of those graphs to evaluate the comparison of the socio economic life of the nation and how that effects the affordability of many necessary things in life and few essential matters that fails to create impact in our rural society. One of such issue is the child birth registration. The data provides the snapshot of the nation and key information that benefits to perform any survey based research. The bar graphs have been used to analyze the classification of the population in statistical perception.
\end{abstract}

Key-words: Bar graph, Birth Registration, Urban, Rural.

\section{GENDER}

Table 1: Gender wise birth registration

\begin{tabular}{|l|c|c|l|c|}
\hline & $\begin{array}{l}\text { Birth is } \\
\text { Registered }\end{array}$ & $\begin{array}{l}\text { Birth is not } \\
\text { Registered }\end{array}$ & $\begin{array}{l}\text { Don't know if } \\
\text { birth is } \\
\text { registered }\end{array}$ & $\begin{array}{l}\text { Number of } \\
\text { children aged 0- } \\
\text { 59 months }\end{array}$ \\
\hline Girls & 53.7 & 42 & 4.2 & 67,517 \\
\hline Boys & 53.4 & 42.2 & 4.4 & 72,065 \\
\hline
\end{tabular}

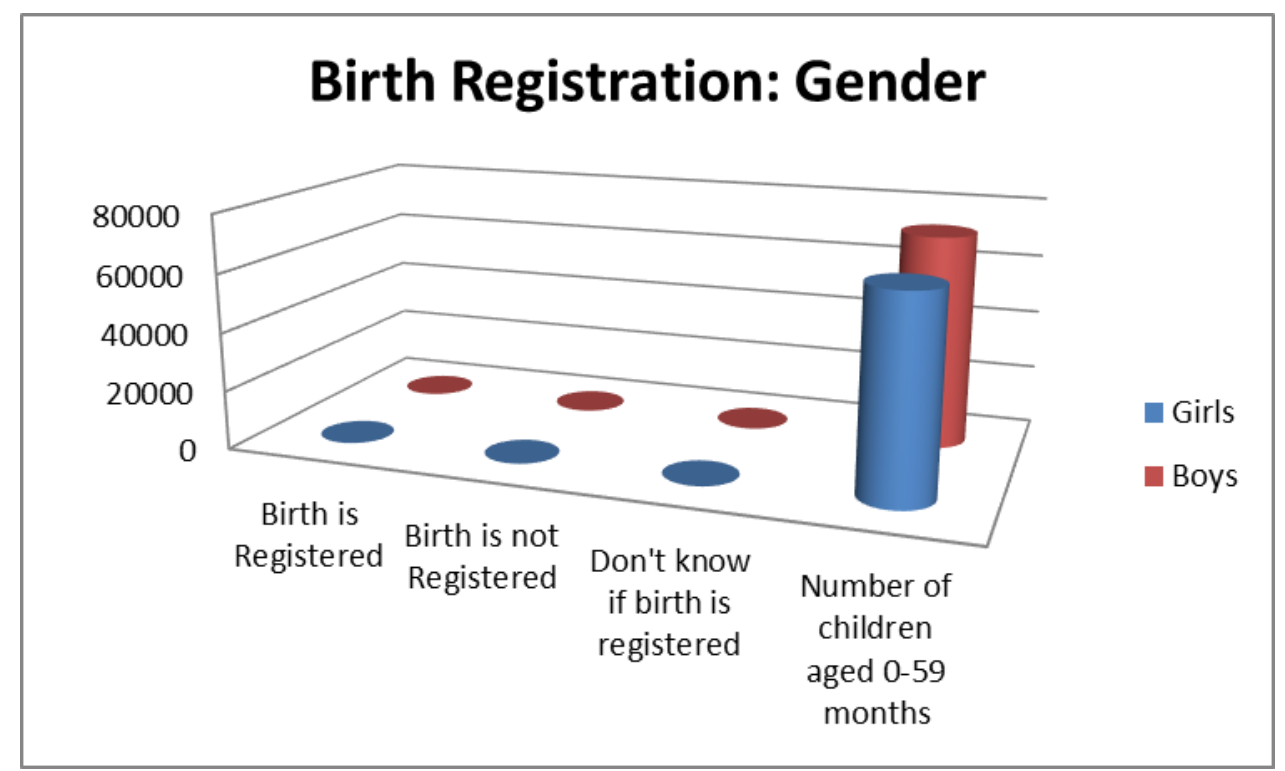

Figure 1.1 Gender wise birth registration, using actual data according to survey 


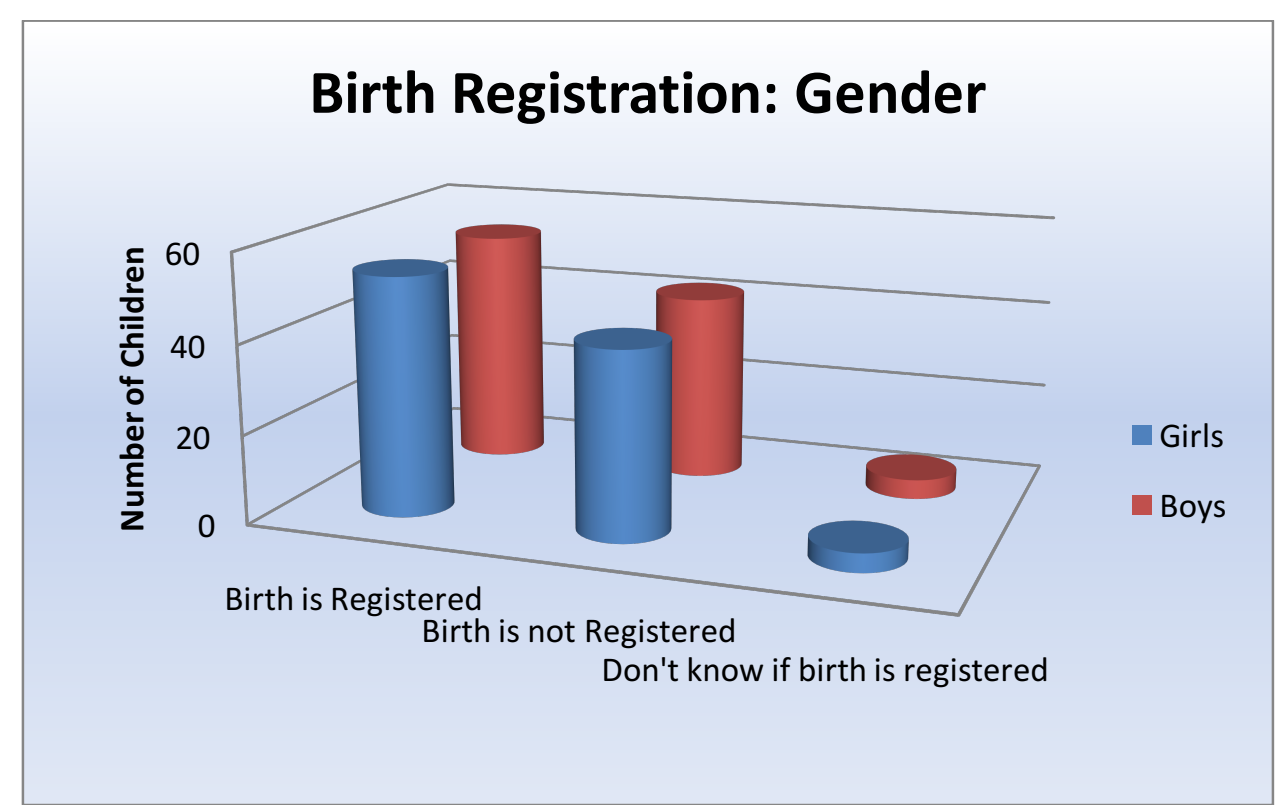

Figure 1.2 Gender wise birth registration, (excluding total number of children)

Birth registration certificate is the first official document and a legal right for a person. British Government broadcasted a law to the greater Indian back then in 1873 regarding birth registration. Throughout these last 118 years, despite the geographical, political and legal changes in the country, the law for birth registration haven't changed. Unfortunately we see a little higher than 50\% boys/girls are registered for the birth certificate.

The government of Bangladesh started "Birth and Death Registration Project" with support of UNICEF in 2001. It was initiated by Local Government. Union council, municipality, cantonment board, city corporations and Bangladesh missions are act as birth registration registrar as per government law of Bangladesh.

Bangladesh government has introduced Online Birth Registration System (BRIS) in the country since October 2010 and slowly moving away the manual arrangement for determination of Digital Bangladesh. This is a totally internet based work. There exists 4571 union council, 319 municipality, 15 cantonment board and 124 zonal office of 11 city corporations with total 5029 register office and in aboard there are 53 registrar office of Bangladesh missions in 42 countries with subtotal of 5082 register office are doing online birth \& death registration for all over the country. In September 2013, the government reviewed the existing law of the birth and death registration and declared to launch Office of the Registrar General of Birth and Death to keep the birth and death database permanent.

It is also possible to check the real time birth registration number and registration/hour [7].

\section{AREAS}

Table 2: Birth registration in rural and urban areas

\begin{tabular}{|l|c|c|c|c|}
\hline & $\begin{array}{l}\text { Birth is } \\
\text { Registered }\end{array}$ & $\begin{array}{l}\text { Birth is not } \\
\text { Registered }\end{array}$ & $\begin{array}{l}\text { Don't know if } \\
\text { birth is } \\
\text { registered }\end{array}$ & $\begin{array}{l}\text { Number of } \\
\text { children aged 0- } \\
\text { 59 months }\end{array}$ \\
\hline Rural & 52.6 & 44.7 & 2.8 & 21,224 \\
\hline Urban & 53.8 & 41.5 & 4.7 & 118,364 \\
\hline
\end{tabular}




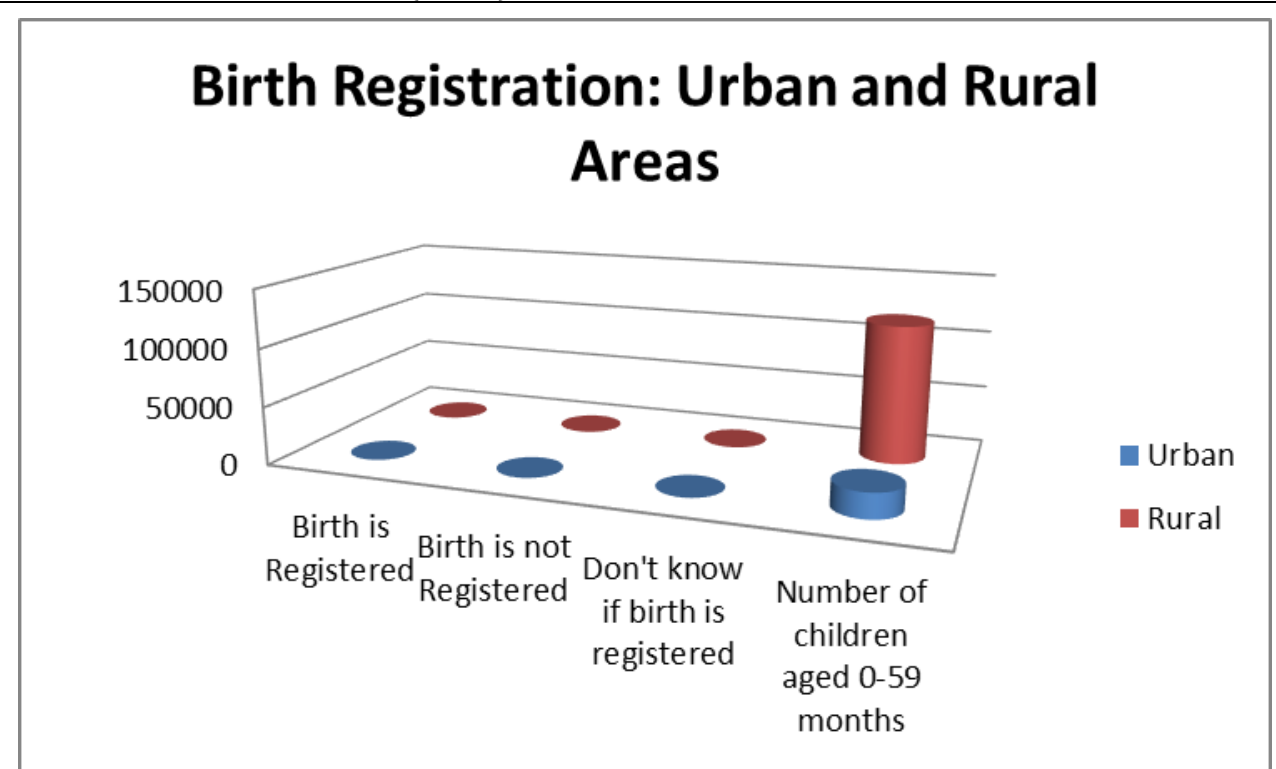

Figure 2.1 Birth registration of Urban \& Rural Areas, using actual data according to survey

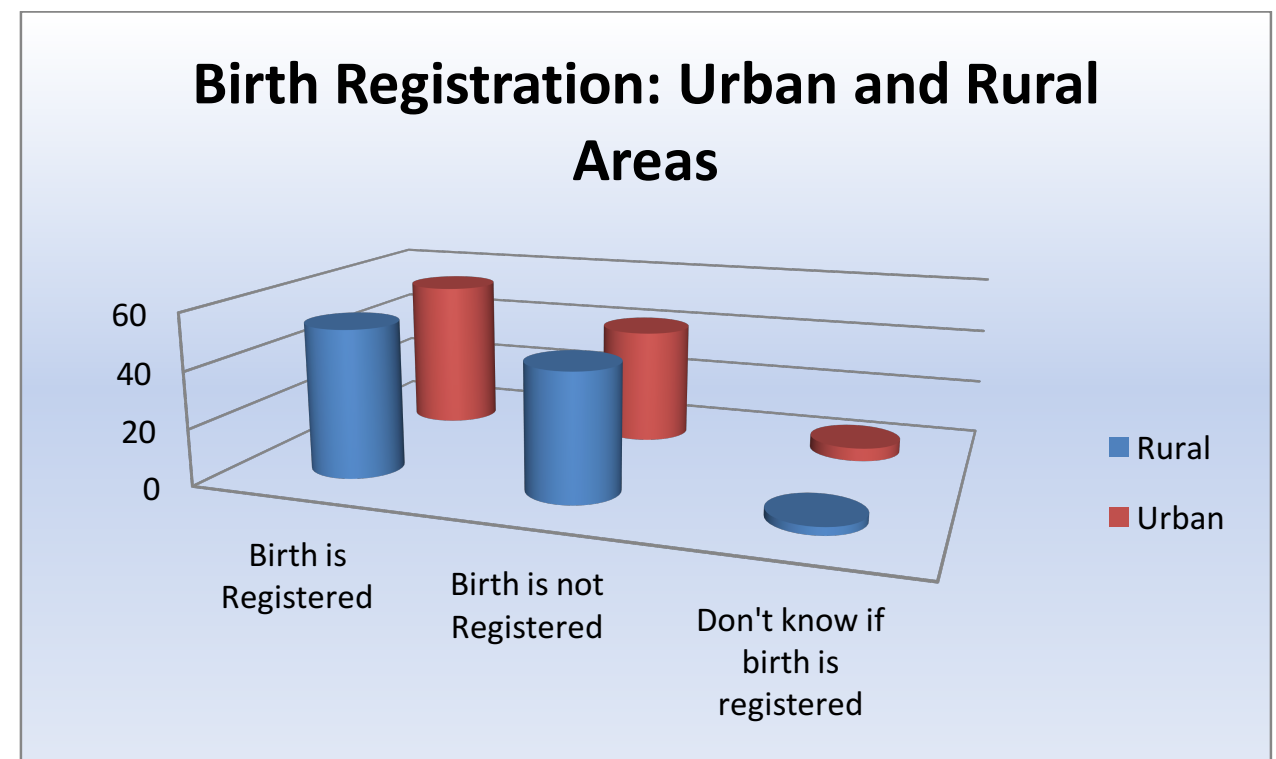

Figure 2.1Birth registration of Urban \& Rural Areas, (excluding total number of children)

The wide mega-city of Dhaka has a huge population. However the majority of the people still live in villages i.e. rural areas. $27 \%$ of the total population is urban population according to the population report of 2009 est. The annual rate of change is 3.5\% from 2005-2010.

Bangladesh is considered an urban country based on their population density. The level of literacy is relatively low, which provides a great impact on the rate of birth registration. It is observed that due to the illiteracy, yet urban people are not aware of the fact about their social rights. Out of those one of the most important one is birth registration of a child.

\section{CATEGORIES IN URBAN AREAS}

Table 3: Birth registration in urban areas

\begin{tabular}{|l|c|c|c|c|}
\hline & $\begin{array}{l}\text { Birth is } \\
\text { Registered }\end{array}$ & $\begin{array}{l}\text { Birth is not } \\
\text { Registered }\end{array}$ & $\begin{array}{l}\text { Don't know if } \\
\text { birth is } \\
\text { registered }\end{array}$ & $\begin{array}{l}\text { Number of } \\
\text { children aged 0- } \\
\text { 59 months }\end{array}$ \\
\hline Slum & 28.6 & 69.1 & 2.3 & 1,239 \\
\hline City corporation & 47.6 & 49.9 & 2.5 & 3,592 \\
\hline Municipality & 57.2 & 39.8 & 2.9 & 16,393 \\
\hline
\end{tabular}




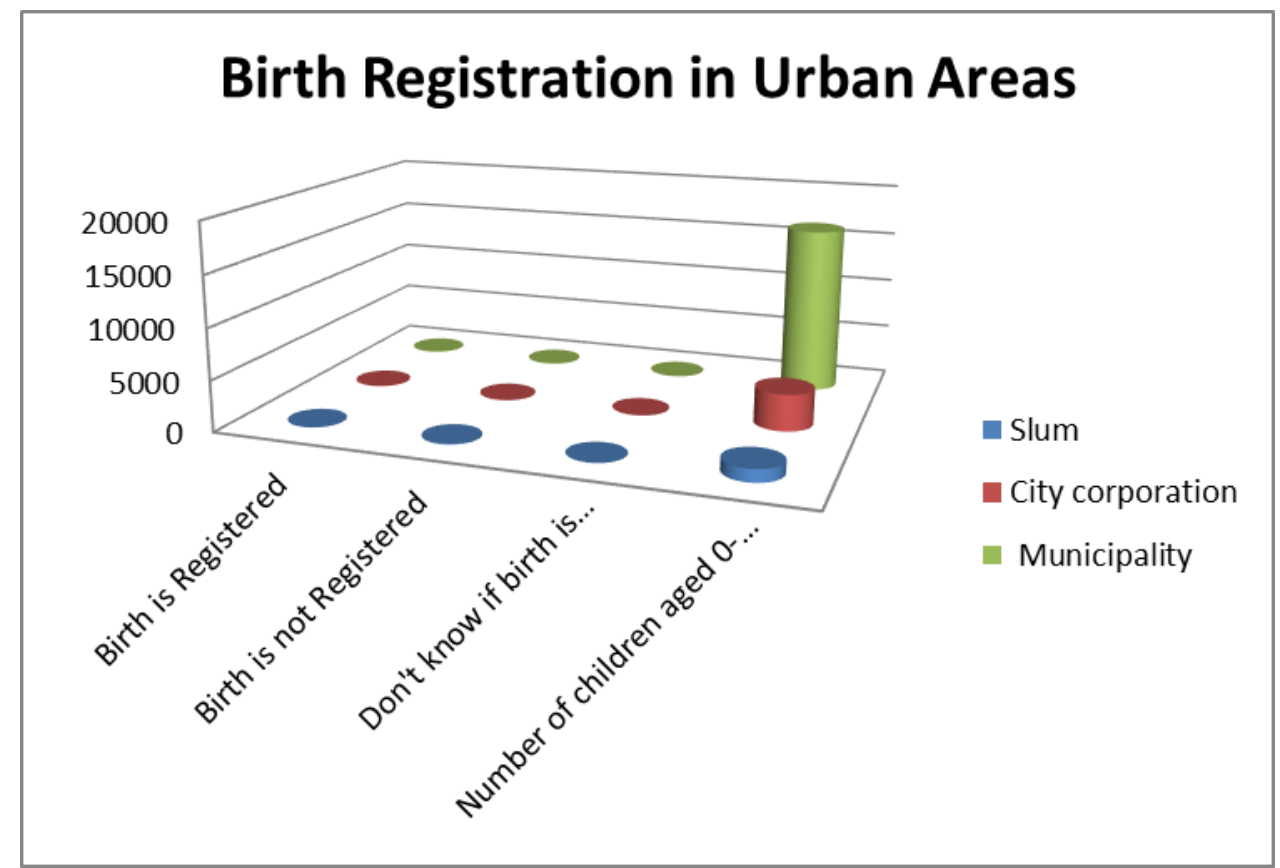

Figure 3.1 Birth registration in Urban \& Rural Areas, using actual data according to survey

\section{Birth Registration in Urban Areas}

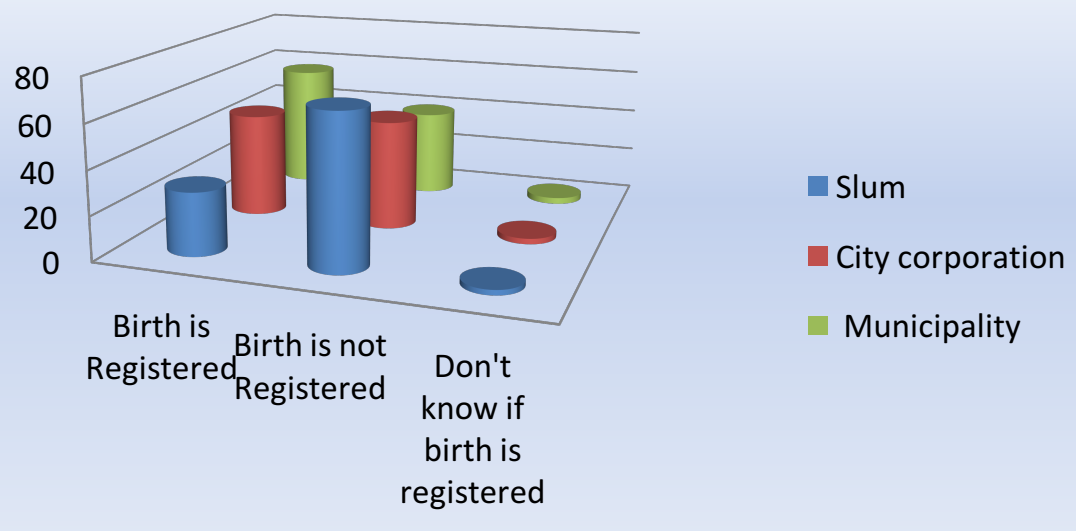

Figure 3.2 Birth registration in Urban Areas, (excluding total number of children)

Poor people mainly live in the slums spread through the city. Most of the slums are located on privately owned land, which creates substantial institutional faces in terms of basic service provision, such as water, gas, electricity services etc. with underprivileged housing structures.

The poor are considerably less educated and have lower school attendance rates than the middle class society. Social services can be fairly far for some slum residents aggravating problems of access since there are shortages of public health clinic and government school. Consciousness of poverty show a chain of command among the poor linked to income, individual's occupation, power, position and networks. Residents of these groups refer to the many hardships of living in slums and massive stresses of everyday life.

There are 11 city corporations and 100+ municipalities in Bangladesh. Though being a part of city residence, due to the lack of information about the services they can obtain form municipalities and city corporations, the dwellers of slums are not receiving their basic rights 
from the society that they earn. One of those is receiving birth certificates of their children. Due to their deficient in of education, the people of slums are unaware of their basic rights.

\section{MOTHER'S OR CARETAKER'S EDUCATION}

Table 4: Mother's or caretaker's education in Bangladesh

\begin{tabular}{|l|c|c|c|c|}
\hline & $\begin{array}{l}\text { Birth is } \\
\text { Registered }\end{array}$ & $\begin{array}{l}\text { Birth is not } \\
\text { Registered }\end{array}$ & $\begin{array}{l}\text { Don't know if } \\
\text { birth is } \\
\text { registered }\end{array}$ & $\begin{array}{l}\text { Number of } \\
\text { children aged 0- } \\
\text { 59 months }\end{array}$ \\
\hline None & 47.6 & 46.7 & 5.7 & 45,382 \\
\hline $\begin{array}{l}\text { Primary } \\
\text { incomplete }\end{array}$ & 53.2 & 42.2 & 4.6 & 23,430 \\
\hline & 54.5 & 41.4 & 4.1 & 19,987 \\
\hline $\begin{array}{l}\text { Primary completed } \\
\text { incomplete }\end{array}$ & 56.2 & 40.4 & & 35,693 \\
\hline $\begin{array}{l}\text { Secondary } \\
\text { completed }\end{array}$ & 61.9 & 35.2 & 2.4 & 9,512 \\
\hline $\begin{array}{l}\text { Higher Secondary } \\
\text { completed }\end{array}$ & 62.4 & 35.1 & & 2.8 \\
\hline Degree and above & 62.1 & 35.3 & 2.5 & 3,160 \\
\hline
\end{tabular}

\section{Mother's or Caretaker's Education in} Bangladesh

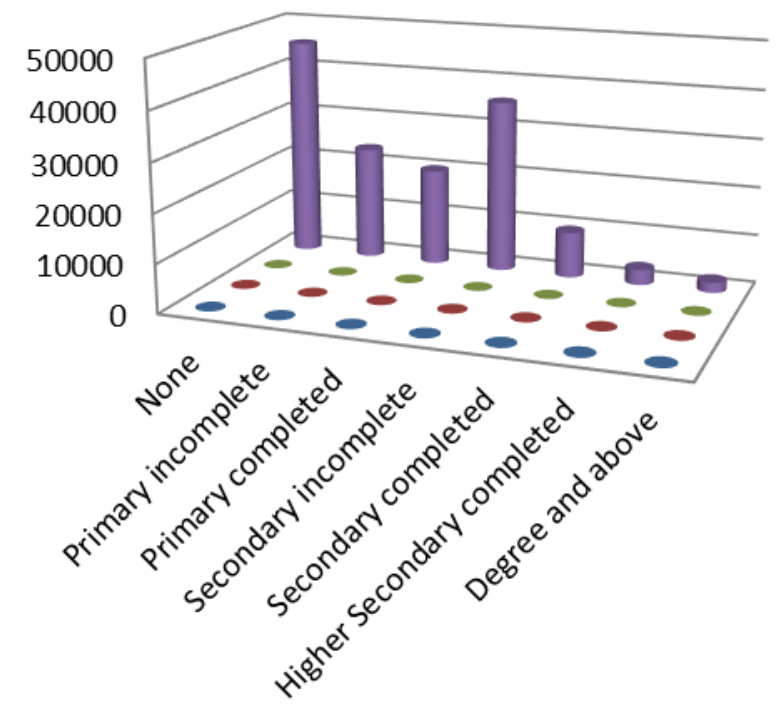

Birth is Registered

Birth is not Registered

Don't know if birth is registered

Number of children aged 0-59 months

Figure 4.1 Mother's or Caretaker's education in Bangladesh, using actual data according to survey 


\section{Mother's or Caretaker's Education in Bangladesh}

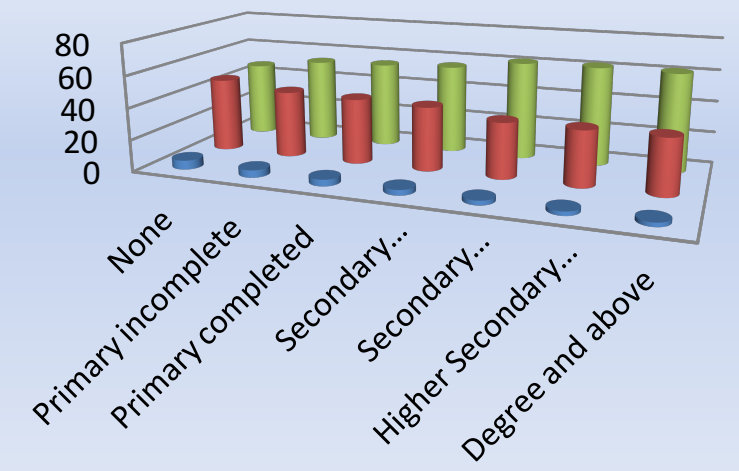

Don't know if birth is registered

Birth is not Registered

Birth is Registered

Figure 4.2 Mother's or Caretaker's education in Bangladesh (excluding total number of children)

The population of Bangladesh is 130 million. Approximately 19 million of these are children who are eligible to attend primary education. They belong to the age group of 6 to 10 years. Apparently, half of them are girls. After attending the primary education, the percentage of girls commences to turn down in the later secondary schools. Approximately 1.5 million primary school age girls are out of school. Due to the poor quality of education, the desired accomplishment level is low for boys and girls. Hence the limited options for girls and women within the greater society aggravate the problems of insufficient schooling for girls. Due to lack of education, women are unaware about their rights and the basic rights of their children. The rate of birth registration is reducing as the level of education is decreasing for women.

A woman is a spinal cord of the house and hence plays a very important role in the society. To improve the morals of our society, we need to educate our women.

\section{CONCLUSION}

Illiteracy is a great problem in Bangladesh. A large portion of the nation's population cannot read or write. So, the literacy rate in Bangladesh is too pitiable. This crisis generates many other tribulations. There are many grounds behind this crisis. Initially, we can mention poverty. Majority of our people live below the poverty line. They can barely manage three meals per day to live. It seems really hard for them to send their children to schools.

Lot of children are dropped out at their early age from schools. These children go out of their home in search of work. Some steps have been taken by the government to solve the problem. Several NGO's are proactive in this matter as well. For example, free primary education has been offered, female education remains free up to secondary level etc.

Deficiency of social alertness is another problem for illiteracy. Most of the parents/guardians are not aware of their Children's education.

In some remote places communication system is not remarkable. Therefore it remains tough for the children to go to school. We need to work together in organizing out the above mentioned reasons wisely to resolve this illiteracy problem of our country.

If we can successfully overcome these situations, we can develop an educated society in future. Hence, we shall be accomplished to solve problems that has been developed due to the illiteracy. 


\section{References}

http://www.thedailystar.net/op-ed/the-number-illiterate-people-bangladesh-larger-entire-populations-someeuropean-countries

http://educationarticle1.blogspot.com/2012/06/illiteracy-problem-in-bangladesh.html

http://collegiatebd.blogspot.com/2013/02/write-paragraph-in-about-120-150-words.html

http://www.aobbangladesh.org/node/132

https://www.google.com.bd/?gws_rd=cr,ssl\&ei=iSo4WPSWD4HxvATOr5bICA\#q=illiteracy+in+bangladesh

http://br.lgd.gov.bd/english.html

http://180.211.213.83/brisreport/ (Real Time BR Data)

www.hrsa.gov

https://en.wikipedia.org/wiki/Demographics_of_Bangladesh\#Urban_and_rural

http://siteresources.worldbank.org/BANGLADESHEXTN/Resources/295759-

1182963268987/dhakaurbanreport.pdf

https://www.unicef.org/bangladesh/education.html 